Int. J. Odontostomat., 10(3):381-384, 2016.

\title{
Forensic Dentistry Job Market in Brazil
}

\author{
Mercado de Trabajo de Odontologia Forense en Brasil
}

Andrea Sayuri Silveira Dias Terada*; Gabriela Ayres de Souza ${ }^{* *}$; Marcelo Afonso Machado ${ }^{* * *} \&$ Ricardo Henrique Alves da Silva ${ }^{* *+*}$

TERADA, A. S. S. D.; DE SOUZA, G. A.; MACHADO, M. A. \& DA SILVA, R. H. A. Forensic dentistry job market in Brazil. Int. J. Odontostomat., 10(3):381-384, 2016.

ABSTRACT: Forensic Odontology is characterized by offer dental knowledge to the Justice system. The Forensic Odontologist, in Brazil, can work in civil, criminal, labor and administrative forums. This research aimed to show the professional profile in the labor market, employability, financial aspects and prospects. The predominant age group comprised from 31 to 40 year-olds and there is a balance between male and females. The Southeast region has the highest rate of professionals and experts believe that the job market is booming in areas that are promising and rewarding. Among the various fields, there is teaching and the position of Forensic Odontologist in police forces through public tenders, the main areas responsible for the increasing interest of dentists for this specialty. It was concluded that there is a heterogeneous distribution of specialists in Forensic Dentistry in the country's different regions however, the labor market appears to be thriving with some branches within the area that can be exploited by professionals.

KEY WORDS: forensic dentistry, job market, specialization.

\section{INTRODUCTION}

Forensic Odontology is one of 22 dental specialties recognized by the Brazilian Federal Council of Dentistry and aims to research mental, physical, chemical and biological phenomena that can reach or have reached the human, alive, dead, bones, and fragments or traces, resulting partial or total reversible or irreversible lesions (Brasil, 2005).

This dental specialty represents the overlap between the dental and the legal professions, the professional expert offers dental knowledge to the Justice system and can perform activities in different areas that include: civil liability, human identification, expertise and audit in health plans, either as a technical assistant (Garbin et al., 2007)

This study aimed to analyze the labor market in Forensic Dentistry in Brazil, through a questionnaire application to Brazilian Forensic Odontologists in order to verify the professional profile and employability, remuneration and career prospects in this area.

\section{MATERIAL AND METHOD}

An online questionnaire was developed in GoogleDocs ${ }^{\circledR}$ (Google Inc., Mountain View, CA, United States) and the invitation was sent to 259 professionals randomly selected from a listing of Forensic Odontologists registered in the Brazilian Federal Council of Dentistry. The inclusion criteria were the acceptance to join the study and the return of the form. The data was analyzed by descriptive statistics.

\section{RESULTS}

In this research, 259 professionals were invited by email and 105 forms returned, representing $40.5 \%$ of the contacted experts. The sample distribution by gender and age is shown in Table I. Regarding the time of undergraduation and the specialization program, the professional participants had finished their undergraduation course about 15 years ago and their specialization 10 years ago, according to Table II.

Department of Pathology and Legal Medicine, Ribeirão Preto Medical School, University of São Paulo, Brazil.

* Department of Stomatology, Public Health and Forensic Dentistry, School of Dentistry of Ribeirão Preto, University of São Paulo, Brazil.

*** Department of Forensic Dentistry, Piracicaba Dental School, State University of Campinas, Brazil.

${ }^{* * * * *}$ Department of Stomatology, Public Health and Forensic Dentistry, School of Dentistry of Ribeirão Preto, University of São Paulo, Brazil. 
Table I Gender and Age of Forensic Odontologists, Brazil, 2014.

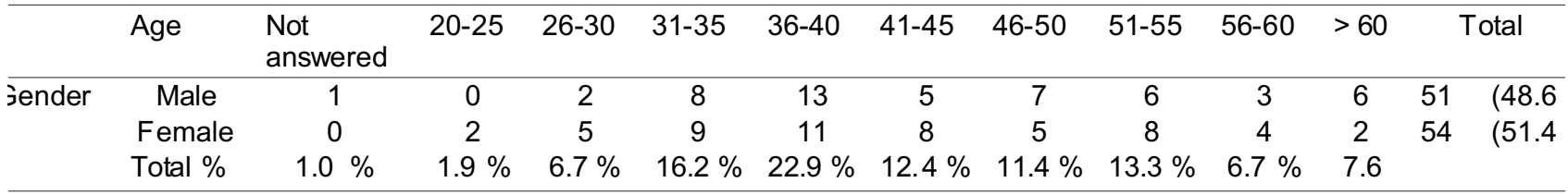

Table II Undergraduation and Graduation conclusion time, in years, Forensic Odontologists, Brazil, 2014.

\begin{tabular}{lccccccccc}
\hline & Not answered & $<5$ & $6-10$ & $11-15$ & $16-20$ & $21-25$ & $26-30$ & $31-36$ & $>36$ \\
\hline Specialization concluded time & 2 & 27 & 35 & 23 & 9 & 4 & 3 & 0 & 2 \\
& $1.9 \%$ & $25.7 \%$ & $33.3 \%$ & $21.9 \%$ & $8.6 \%$ & $3.8 \%$ & $2.9 \%$ & $0 \%$ & $1.9 \%$ \\
Jraduated time & 3 & 3 & 21 & 23 & 10 & 12 & 16 & 10 & 7 \\
& $2.9 \%$ & $2.9 \%$ & $20.0 \%$ & $21.9 \%$ & $9.5 \%$ & $11.4 \%$ & $15.2 \%$ & $9.5 \%$ & $6.7 \%$ \\
\hline
\end{tabular}

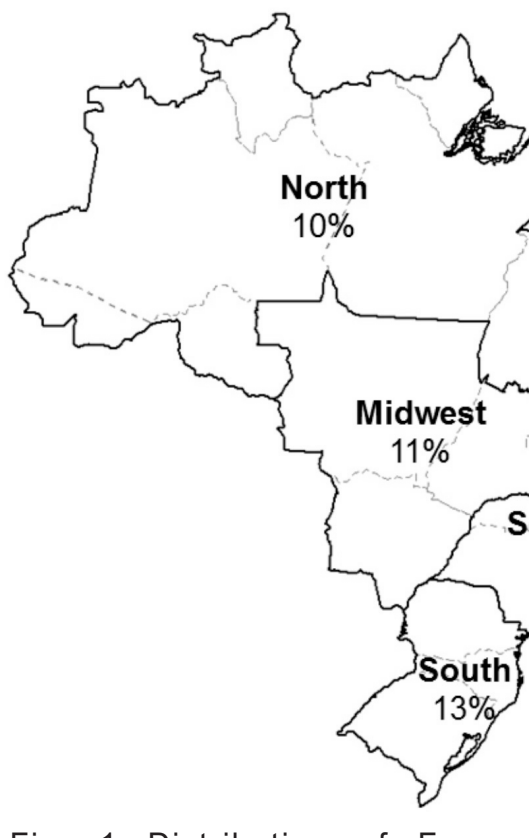

Fig. 1 Distribution of Forensic Odontologists in Brazilian regions, 2014.

The geographical distribution showed that the Brazilian Southeast region included the majority of Forensic Odontologists, followed by the South and Northeast Brazilian regions (Fig. 1). Considering the professionals who participated in the search, $74 \%$ are concentrated in the States' capitals.

The results also showed that $50.4 \%$ of Forensic Odontologists have another dental specialization, highlighting Periodontics, Restorative
Dentistry, Prosthodontics and Surgery. It was also observed that some professionals have another college degree (62.8\%), highlighting Law, Management, Nutrition, Psychology, Biomedical, Medicine, among others.

Regarding the work place, $63 \%$ work teaching, and the second area is the dental malpratice litigance expertise (Fig. 2). When asked about the labor and employment market, $32 \%$ believed that it is bad or saturated, while $58 \%$ think that is expanding.

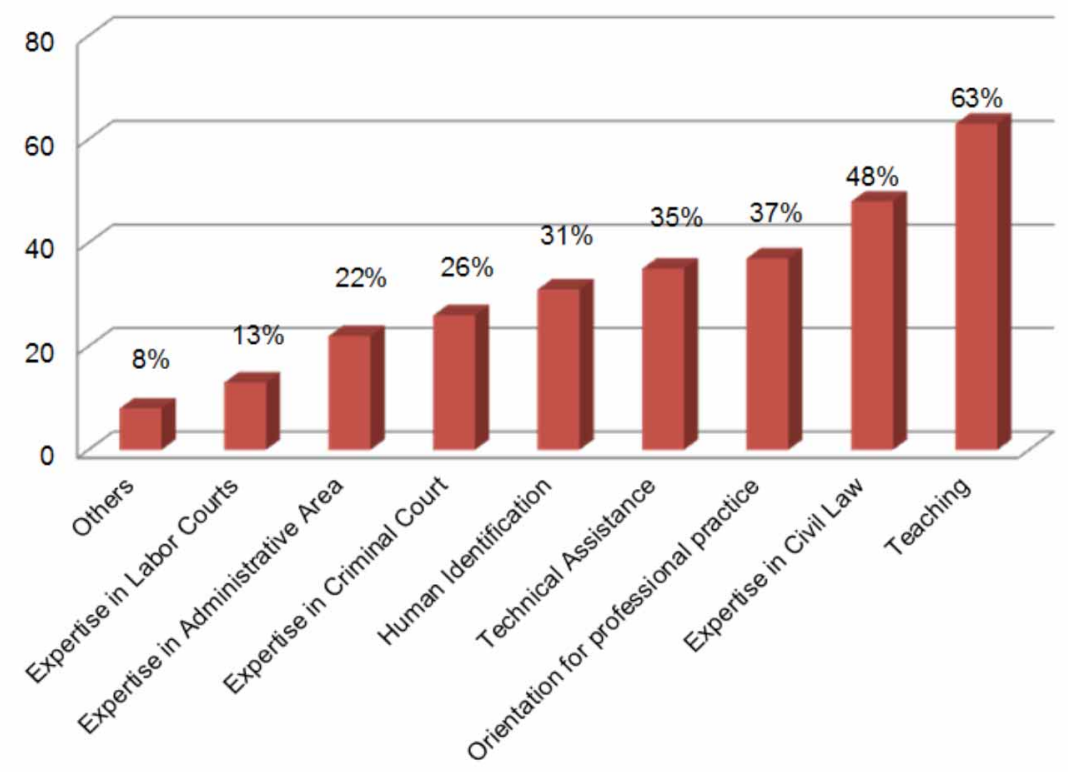

Fig. 2 Forensic Dentistry practice areas reported by the Forensic Odontologists, Brazil, 2014. 


\section{DISCUSSION}

In Brazil, the specialist license is obtained through a graduate course (specialization program) and applying for registration to the Brazilian Federal Council of Dentistry. According to updated data, in 2015, there were 261.901 dentists registered, and only 623 of these are registered as Forensic Dentistry experts. Even considering an increased number of Forensic Dentistry specialists in the last decade, the number is considered lower than other specialties, for example, Prosthodontics with 10.590 and Endodontics with 13.802 registered professionals (CFO, 2015).

While constantly being associated with human identification, the performance of the Forensic Odontologist is much broader and includes different fields. In civil liability issues, the dentist can work as an Expert Witness, in order to report technical considerations to the Judge, or can participate as Technical Assistant of one of the persons involved (for example, to the dentist or the patient), and has the obligation to analyze the Expert report (Paranhos et al., 2008; Silva et al., 2009).

In the criminal area, the experts usually work in Forensic Institutes and may participate with live victims, when examining dental injuries, or, after death, for example, in human identification, cases of social relevance, mainly when the victim were found charred or putrefied (Gonçalves et al., 1999).

In the labor area, exams can be performed on accidents during professional activity or occupational diseases, both of them with oral injuries (Marques et al. 2013). In administrative area, it is possible to perform audits in health security plans (Peres, 1997).

There is a balance in both sexes groups working in the area. In a survey conducted in 2009 , the authors showed a percentage of $51.8 \%$ for the male sex (Paranhos et al., 2009). In this study, despite maintaining a balance among the respondents of the survey, there was a trend towards increased female experts observed.

Regarding the distribution of Forensic Dentistry specialists in Brazil, it became evident that the professionals work mainly in the states of the Southeast and South and are concentrated in the capital cities of these regions. This might be related to the fact that these professionals work as Professors at universities, as well as Experts in dental malpractice litigation for the State Courts and criminal investigation in police forces, and, in many states, most Universities and the Forensic Institutes are located in these cities.

While the traditional Dentistry (with clinical activities) is currently in crisis, justified by the increased number of undergraduate courses (as the number of dentists) (Junqueira et al., 2005) most of the participants of this research considered that the job market in Forensic Dentistry is expanding.

The increase of the dental insurance in recent years requires higher service quality (Peres). Thus, expanding dental audit services, one of the fields performed by the Forensic Odontologist, which requires an understanding of proper techniques and ethically appropriate Dentistry.

The difficulties in the labor market can lead some professionals to act inappropriately, favoring unfair competition and contributing to the disunity of professionals (Junqueira et al.). The irregularity in professional practice indirectly favors the Forensic Dentistry market, because of increasing number of lawsuits by patients against dentists related to dental treatment (Terada et al., 2014 a), makes the work of experts and technical assistants important and necessary (Silva et al., 2009).

In many countries, the experts must register with the Courts, and thus can be called to act in litigation involving dentists. Just as in Brazil, in these countries the expert can be a dentist without specialized knowledge and experience, not the most appropriate procedure (Nuzzolese \& Cukovic-Bagic, 2012). The professional who has completed the graduation course knows the court proceedings and is well prepared to act in such cases.

Another important field for Forensic Odontologists is career guidance for other dentists, in this type of service the expert gives suggestions about the dental office organization, as well as work related to dental records (Garbin et al.), and the increase of litigations where professionals feel insecure and look for more knowledge about ethical and legal aspects that guide the profession in security of clinical practice (Terada et al., 2014 b).

In an attempt to remain active in the labor market, it is indicated to experts seeking alternatives such as internalization, or the search for areas of activity expanding (Jeunon \& Santiago, 1999). This fact may be related to that observed in the present study, which showed that more than a half recorded a second specialty $(50.4 \%)$, or other college or other post-graduate course in areas other than dentistry $(62.8 \%)$. 
It should also be noted that was evidenced by the participants of this research a lack in disseminating and encouraging the specialty, mainly in universities during the undergraduation course. This can be changed through lectures and practical classes to increase the interest of students in this field. This fact is also observed by other authors who claim that the basic principles and techniques should be exposed to the students, not in order to enable them to acting in criminal cases, but in order to allow recognition of forensic cases with dental application (Acharya, 2006). In addition, it is important that dental associations and societies organize advertising campaigns to present and clarify the Forensic Dentistry importance to society as a whole.

It can be concluded that there is a heterogeneous distribution of Forensic Odontologists in the Brazilian regions, however, the labor market appears to be growing, with areas into the Forensic Dentistry that can be explored.

TERADA, A. S. S. D.; DE SOUZA, G. A.; MACHADO, M. A. \& DA SILVA, R. H. A. Mercado de trabajo de odontologia forense en brasil. Int. J. Odontostomat., 10(3):381-384, 2016.

RESUMEN: La Odontología Forense, se caracteriza por ofrecer a la justicia, el conocimiento dental. El Odontólogo Forense en Brasil, puede desempeñarse en materia civil, penal, laboral y administrativa. El objetivo de la investigación fue evaluar el mercado de trabajo para los especialistas en Odontología Forense, tratando de conocer el perfil profesional, aspectos de empleabilidad, remuneración y perspectivas de estos profesionales. El grupo de edad predominante comprende de 31 a 40 años de edad y existe un equilibrio entre hombres y mujeres. La región sudeste tiene el mayor número de profesionales y los expertos consideran que el mercado laboral se está expandiendo en sectores prometedores y bien pagados. Ent re los diversos campos de la actividad, está la docencia y la posición de Odontologo Forense en las fuerzas policiales a través de concursos públicos, son éstas, las principales áreas responsables del creciente interés de los Dentistas por ésta especialidad. Se concluye, que hay una distribución heterogénea de profesionales especialistas en Odontología Forense, entre las regiones de Brasil, sin embargo, el mercado laboral parece estar creciendo, con algunas ramas dentro del area que pueden ser explotadas por los profesionales.

PALABRAS CLAVE: odontología forense, mercado de trabajo, especialización.

\section{REFERENCES}

Acharya, A. B. Teaching forensic odontology: an opinion on its content and format. Eur. J. Dent. Educ., 10(3):137-41, 2006.

Conselho Federal de Odontologia. Totalização Geral dos Inscritos em Atividade no Brasil. São Paulo, Conselho Federal de Odontologia, 2015.

Garbin, C. A. S.; Garbin, A. J. I. \& Dossi, A. P. O O mercado de trabalho para o especialista em Odontologia Legal. R. P. G. Rev. Pos. Grad., 14(2):184-90, 2007.

Gonçalves, A. C. S.; Travassos, D. V. \& da Silva, M. Campo de atuaçäo do odontolegista. R. P. G. Rev. Pos. Grad., 6(1):60-5, 1999.

Junqueira, C. R.; Ramos, D. L. P. \& Rode, S. M. Considerações sobre o mercado de trabalho em Odontologia. Rev. Paul. Odontol., 27(4):24-7, 2005.

Marques, J. A. M.; Musse, J. O.; Musse Netto, J.; Camanho, E. D. L.; Rosário, H. D. \& Paranhos, L. R. Aspectos legais das perícias ocupacionais em Odontologia. Rev. Fac. Odontol. U. P. F.,18(2):230-4, 2013.

Nuzzolese, E. \& C'ukovic'-Bagic', I. Expert witnesses in dentistry: a comparison between Italy and Croatia. J. Forensic Odontostomatol., 30 Suppl. 1:29-39, 2012.

Paranhos, L. R.; Ramos, A. L.; Scanavini, M. A. \& Ricci, I. D. Análise do mercado de trabalho odontológico na região Sudeste do Brasil. Rev. Assoc. Paul. Cir. Dent., 63(1):57-63, 2007.
Peres, A. S. Perícia de Convênio. São Paulo, Faculdade de Odontologia da Universidade de São Paulo; 1997.

da Silva, R. H. A.; Musse, J. O.; Melani, R. F. H. \& Oliveira, R. N. Responsabilidade civil do cirurgião-dentista: a importância do assistente técnico. Rev. Dent Press Ortodon. Ortop. Facial, 14(6):65-71, 2009.

Terada, A. S. S. D.; de Araujo, L. G.; Flores, M. R. P. \& da Silva, R. H. A. Civil liability of dental surgeon: Legal proceedings analysis in the city of Ribeirao Preto, São Paulo State, Brazil. Int. J. Odontostomat., 8(3):365-9, 2014a.

Terada, A. S. S. D.; Galo, R. \& Silva, R. H. A. Responsabilidade civil do cirurgião-dentista: conhecimento dos profissionais. Arq. Odontol., 50(2):92-7, 2014b.

Correspondence to:

Ricardo Henrique Alves da Silva

Faculdade de Odontologia de Ribeirão Preto - USP

Departamento de Estomatologia

Saúde Coletiva e Odontologia Legal

Avenida do Café, s/n

Monte Alegre - Ribeirão Preto/ SP

BRASIL

Email: ricardohenrique@usp.br

Received: 14-01-2016

Accepted: 26-09-2016 